\title{
Students' Views of the Architectural Design Review: The Design Crit in East Africa
}

\section{Abstract}

The design studio and the associated design review can be regarded as the signature pedagogy of architectural education, where students garner the essence of what it means to be an architect. Here novices are transformed into architects through the acquisition of architectural cultural capital. This paper investigates the design review in East African schools of architecture from a student's perspective, garnered from focus group discussions carried out in the five schools of architecture, and corroborated through observations. Findings indicate challenges in the design review, vis-à-vis the broader goals and objectives of architectural education. However, it did uncover attempts at change, via a 'back seat instructor approach', for example, breaking down the stereotype of the design review as a hostile environment for students. The paper concludes with a few recommendations to help recast this signature pedagogical approach as a truly discursive environment.

Keywords: Architectural education; Design crit; Design review; East Africa; Power relationships; Signature pedagogy; Teaching quality 


\section{Students' Views of the Architectural Design Review: The Design Crit in East Africa}

\section{Introduction}

"if you wish to understand why professions develop as they do, study their nurseries, in this case, their forms of professional preparation" (Shulman, 2005: 52).

The design studio and associated design review are at the core of architectural education; where students garner the essence of what it means to be an architect, through strong social connections with instructors, and fellow students. These activities form the signature pedagogy of architectural education, which are the:

types of teaching that organize the fundamental ways in which future practitioners are educated for their new professions ... simplify[ing] the dauntingly complex challenges of professional education because once they are learned and internalized, we don't have to think about then; we can think with them (Shulman, 2005: 52-56).

As a signature pedagogy, the design review is where students acquire architectural cultural capital, through evaluating, synthesising, and presenting ideas (Gul and Afacan, 2018). The design review (also known as the Crit, Dialogue, Jury, Pin-ups, or simply Presentations), is where 'discourse' takes place between students and instructors (also referred to as Facilitators, Studio Masters, Studio Tutors, Studio Faculty or more generally, as Teachers). Design reviews generally comprise formal presentations by students in front of a panel of academic staff from within the faculty, or with the assistance of external jurors. This setup, derived from the Beaux-Arts Atelier system, ties architectural education to its apprenticeship origins, which Boyer and Mitgang suggest provides a "... sense of kinship with centuries of traditions, thoughts, and personalities ... the true tie that binds those who practice architecture with those who teach it and study it" (1996: 4).

Studies of the design review have compare it to "... the hazing rituals that young men undergo during their induction into fraternities" (Anthony, 1991: 3), and where "some of the most gifted students of architecture simply break down because they never understood the motives and purpose behind the Jury assessment" (Aderonmu et al., 
2017: 4). Statements of this nature suggest the design review may not be the discursive learning environment often presented (McClean and Hourigan, 2013; Osborne and Crowther, 2011). According to Webster (2007), it may instead promote a hegemonic relationship between instructors and students, ensuring the design review is placed under increased scrutiny with relation to: its construct and effectiveness (Anthony, 1991; Boyer and Mitgang, 1996; Cuff, 1991; Sara and Parnell, 2013; Vowles, 2000; Webster, 2005); relations between instructors and students (Goldschmidt et al., 2010; Webster, 2007; Webster, 2006), and; assessment and learning outcomes (Aderonmu et al., 2017; Wilkin, 2000). These studies also revealed less than cordial design review sessions, a result of its ritualistic format, with members of the jury sitting directly in front of the presenting student, whose work is spread out for all to see. Guests, if permitted, sit behind the jurors, and are generally not permitted to comment or ask questions - the privy of jurors. As a consequence, the collegial atmosphere expected of these sessions, is often replaced by opposing actors - Jurors as both the Judge and Executioner), with the presenting student as the hapless defendant, but without supporting representation.

Reflecting on conduct within the design review, anxiety, fear, and tears, are at times evident, affecting how students present, how students engage with instructors, and how anxious students respond; making for rather uncomfortable proceedings (Dannels, 2005). There are strong suggestions that these nuances may be a consequence of the approach to teaching within architectural education, leaving a profound and lasting effect on students (Olweny, 2017; Olweny, 2015). The importance of teaching on student engagement in the design review, not withstanding, this study seeks to engage with the student perspective, complementing findings from earlier studies undertaken on the topic. The findings also contribute to investigations of the design review in the context of sub-Saharan Africa, which thus far only include: Alagbe et al. (2015), Alagbe et al. (2017) and Aderonmu et al. (2017) in Nigeria, as well as Coetzer (2010) in South Africa. While revealing some similarities with studies conducted in other parts of the world, these studies also disclose intriguing context specific subtleties, making this investigation of the design review in East Africa a compelling prospect.

The paper begins with a literature review exploring global discourse on the design review, and the attendant elements relating to this activity. This leads into the main 
study undertaken through a rereading of data gathered as part of a wider study of socialisation in architectural education in East Africa by Olweny (2015). Socialisation defined by Bragg as "[...] that process by which individuals acquire the values, attitudes, norms, knowledge, and skills needed to perform their roles acceptably in the group or groups in which they are, or seek to be, members" (1976, p. 6). This sets the stage for the current study, which seeks to consolidate data on student perspectives of the design review in architectural education across East Africa, as a crucial step in understanding architectural education in the region, while at the same time contributing to global discourse on the same.

\section{The Design Review in Architecture Education}

Unique to creative disciplines, and a major component of the signature pedagogy of architecture education, the design review presents with its own norms, standards of objectivity, and fairness (Webster, 2005). This is where students present work to a panel of examiners, engaging in the discourse of architecture through questions, comments, and advice geared to improving or enhancing design outcomes (Oh et al., 2013; Schön, 1985). Successful outcomes in the design review are generally tied to expectations of a cordial relationship between instructors and students (Osborne and Crowther, 2011), and evident in the various definitions of the design review. Sara and Parnell for example describe the design review as “... the place where design work is shared, critiqued, reviewed and developed" (2013: 102). From a student point of view, Doidge et al., state:

\footnotetext{
The review is a learning experience; The review allows you to build your presentation skills for later life in practice; Participation in review discussions can develop your understanding of architecture; The review allows you to hear a variety of opinions and ideas about your work; The review allows you to see other people's work; and develop critical thinking; The review is what you make it (2000: 16-19).
}

The design review is also presented as a stand-in for client reviews, a simulation of professional practice, where instructors act as stand-ins for clients. A key argument for this engagement being that this prepares students for the often unpredictable and unscripted nature of practice, although it is not always clear if this idea is effectively translated into design review sessions. Stevens, suggests the design review places 
students "... in a permanent state of insecure expectation" (1995: 119), with students employing different tactics to get through the process without "getting killed" (Webster, 2007: 24). Under these conditions, the “... students' fate ultimately rest[s] 'in the hands of the gods' ... who decided whether they passed or failed" (Anthony, 1991: 9). The design review as a subjective process, has earned a mythical reputation, a cause of student's feeling of vulnerability, and a threat to their selfesteem. This makes learning difficult at best, with the need to master the mystery (Argyris and Schön, 1974) and a barrier to open and frank discussion (Hattie and Timperley, 2007; Osborne and Crowther, 2011). Conduct within the design review, is itself a challenge, with interactions in different schools indicating that teaching is largely based on instructors' prior experiences as students, “... learned from their experience of passing through the same ritual as students, and honed through their repeated experiences now as the elders of the process" (Sara and Parnell, 2013: 102). This does raise questions of teaching competence in architectural education, and linked to quality of teaching, more so in the design studio and the associated design review. With both instructors and their students approaching this educational engagement through an 'apprenticeship of observation' approach (Shulman, 2005), both the processes and outcomes are thus open to question. A consequential outcome is seen in how students approach design review sessions, cautious not to subject themselves to the wrath of instructors. This generates an atmosphere very different from the decorum expected of this signature pedagogy. In this regard, Osborne and Crowther (2011), suggest that the traditional design review is antiquated and does not align with good educational practices, more so with student bodies becoming more heterogeneous (Fung, 1996), a reality that has brought forth previously unseen issues in relationships between instructors and students. These issues, according to Boyer and Mitgang (1996), have come to undermine the strengths and advantages of this pedagogical approach.

The need to investigate the design review in architectural education was made more apparent through studies that made use of critical or 'alternative' methodological approaches, as done by Anthony (1991) and Shannon (1995), who made use of feminist methodological approaches in their studies. Smith (2011) took a different approach, making use of ethnographic methodology geared to allow students views to surface. Emerging from these 'alternative' approaches, were evident 
contradictions; while the design review is regarded as dialogical, “... one of the parties speaks from a position of authority" (Osborne and Crowther, 2011: 1). This reiterates what Boyer and Mitgang noted as, “... the autocratic, one-way communication that often marks design juries'- the tension-packed ritual during which invited critics, including faculty, practicing architects, and more rarely clients, review and critique student work" (1996: 8-9). With architecture students going through numerous design reviews during their formal education, there are questions of the effect this has on students, and how this sets parameters for success or failure in architectural education (Gul and Afacan, 2018; McClean and Hourigan, 2013).

In the context of East Africa, socio-cultural nuances, such as patriarchal and seniority, are additional elements influencing educational endeavours. These define how individuals relate with each other within the educational setting, as presented by Owuor:
... African students who have been immersed within a conservative cultural setting that value authority of elders may find it challenging to express divergent views from their teachers, hence limiting the process of dialogue in the classroom and instead promoting the authoritarian ... This might not be appreciated by conservative teachers who maintain traditional beliefs on the central role of teachers in the legitimacy of knowledge construction based on their cultural beliefs on ownership of knowledge and authority in the classroom (2007: 28).

Asymmetrical power relationships of this nature influence everything from peer learning, collaboration and teamwork, to interactions between instructors and students, and may act as obstacles to learning. This is further heightened by a social structure that equates knowing with seniority, and where elders are not to be questioned:
... knowledge and wisdom is perceived to advance with the age of individuals based on their experiences with life ... African indigeneity cultivates respect for the authority of knowledge of community elders due to their wisdom, accumulated knowledge, and their closeness to the ancestral world (spirituality) (Owuor, 2007: 23-28).

On top of this system is an imposed structure, presenting education as the "[...] transmission of packaged, or pre-digested, information - education as instruction 
administered to the 'ignorant' by experts [...]" (Mills and Lipman, 1994: 215). Here, knowledge is viewed as proprietary, held in the hands of teachers who (reluctantly) pass it on to students. This is somewhat tied to the idea of disciplinary power (Gore, 1995), largely derived from modern institutions - such as the military, religious institutions, and schools - instilling in students the notion of subordination, the acceptance of which ensures individuals participate in their own subjugation. Under these circumstances, students expect to be provided with all the knowledge and skills to make them experts (Olweny, 2015).

For students, success in the design review, is not only tied to learning expectations, and the relationship between instructors and students, but also to elements that are often taken for granted, but nevertheless important in this pedagogical approach. While the design review is, presented as a celebrated component of the signature pedagogy of architectural education, a number of underlying factors suggest the need to interrogate the design review through the otherwise hidden or silent voices of students, to engage with learners as key participants in this activity, seeking to go beyond the ever-present authoritative expert (Esser-Hall et al., 2004).

\section{Methodology}

This study of the architecture design review in East Africa, makes use of data gathered as part of an earlier study of architectural education undertaken earlier by Olweny (2015). That study investigated processes of socialisation in architectural education in five established architecture schools across East Africa, making use of an ethnographic methodological approach, acknowledging that ethnographical research "... bears a close resemblance to the routine ways in which people make sense of the world in every day life" (Hammersley and Atkinson, 1983: 2). Focus group discussions were the primary means of collecting data, an approach in which groups of individuals discussed issues of mutual importance, delving into topics the group regarded as important. This provided opinions, and perspectives through unscripted narratives, enabling otherwise hidden or silent voices, and true experiences to emerge (Cook-Sather, 2002; Esser-Hall et al., 2004). Focus groups also ensure often-suppressed voices are heard; more so in face of methodological challenges such as courtesy and interviewer bias (Bulmer and Warwick, 1993; Camfield et al., 2014) that can affect cross-cultural research. In the context of East 
Africa, focus groups take on added significance, with oral tradition retained as a safe means of transmitting [privileged] information [and knowledge].

Eight (8) focus group sessions were held across five schools of architecture in Kenya, Tanzania and Uganda. Responding to calls distributed within the different architecture schools, sixty students and recent graduates (thirty-nine (39) male and twenty-one (21) female) took part, representing all levels of the architectural programmes. The focus groups provided an opportunity for students to discuss issues they regarded as important, while providing opportunities to query opinions, attitudes, experiences, and perspectives of participants. Discussions were recorded using Sound Studio ${ }^{\mathrm{TM}}$ and Voice Memos $^{\mathrm{TM}}$, producing over twelve hours of audio recording, and transcribed with the aid of Sound Studio ${ }^{\mathrm{TM}}$ and iTunes ${ }^{\circledR}$. Transcripts were marked-up with the help of notes made during discussions, that captured the person speaking, the time they started, and where possible, behavioural gestures, in line with suggestions by Jo and Lee (2007), serving to simplify the transcription process. However, as noted by Hammersley and Atkinson (1983), behavioural nuances are often difficult to reconstruct and transmit accurately in text form, thus it was acknowledged that some fine-grain detail contained as part of nonverbal communication would be lost during the process of transcribing discussions, more so as video recordings could not be made; nevertheless this was not expected to adversely affect the analysis of the information.

Data from the focus group discussions was analysed using Template Analysis, also known as Key Point Coding (Allan, 2003), or Constant Comparison Analysis (Onwuegbuzie et al., 2009). This is a means of thematically categorising and analysing qualitative data, and particularly accommodating in the management of qualitative data derived from multiple focus groups. To cope with the large volumes of data, TAMS Analyzer ${ }^{\mathrm{TM}}$ (Version 4.42) a text analysis mark-up system was used, enabling multi-dimensional analysis and evaluation of data. The data from the focus group discussions was augmented by on site observations in the schools, which was key to clarifying issues in a naturalistic setting. Observations of design reviews in progress were carried out in three of the schools, during presentations for the final project proposals at Part 1 (third year) and Part 2 (fifth or sixth Year). Observations scrutinised the setting of the design review, behaviour, gestures, language and intonation of students during presentations, as well as their interactions with 
audience, particularly members of the jury. Observations were useful in building as appreciation of the context in which the design review was undertaken, and revealing the cultures and subcultures of the different schools. Regardless, far from being indisputable facts, subjective data from these observational studies required vetting by two colleagues to ensure consistency in reading of the data, as recommended by Graneheim and Lundman (2004). This also raises questions of the nature of responses provided by students, and whether they might have been different had the study been directed specifically at evaluating the design review. With responses emerging out of conversations related to architectural education and corroborated by observations in the different schools, this would discount the possibility that selfselected discussants were disgruntled with the programme, and only using this opportunity to air their grievances.

\section{Perceptions of the Design Review}

With the design review at the core of architectural education, investigating this phenomenon in the context of East Africa was viewed as an important part in building an understanding of the educational process across the region. With the data derived from focus group discussions, that covered a wide range of issues, a means to parse the acquired data, wan needed, and found in the fundamental factors of the design review, as presented by Oh, et al. (2013). Within this framework were two broad categories: i. Critiquing Methods - related to the way instructors convey design knowledge and skills to students, and; ii. Critiquing Conditions - linked to the context in which critiquing occurs; both being specific to particular phases of a design activity. For this particular study, critiquing methods were of particular interest, as they directly relate to interactions between instructors and students. Five key factors identified by Oh, et al. (2013) as influencing these activities are presented below:

Setting - Context in which instructors interact with students, privately or publicly, varying with the stage and intentions of the session;

Teacher-student relationship - Modes through which students and instructors interact (master - apprentice, user - designer, or peer critiquing); 
Communication modalities - Modes of presentation and communication between instructors and students, including: conversations, written comment, drawings, or gestures;

Delivery types - The way comments are delivered, as either facilitative, or directive, to either introduce or remind students of issues or strategies through descriptions of existing examples or analogies;

Delivery methods - Behaviouralism's as part of communication, such as body language, intonation and loudness, and style of drawing.

These five factors provide a means to categorise the different interactions within the design review, as presented in the discussions, and observed in the schools.

\section{Setting}

It is widely acknowledged that the setting in which the design review occurs can either aid or detract students in their presentations (Oh et al., 2013). For the schools included in the study, end of semester reviews were generally undertaken in one of the studio spaces. Setups were similar, with students displaying their work on boards, with the jury seated at the front, in a setup that overtly displayed the power relationships between members of the jury, and the students. All schools had open design review sessions, with anyone able to observe proceedings, although nonparticipant observers were required to stand or sit behind the jury. Students waiting to present were observed standing further back, or in some cases still frantically pinning up their work in preparation for their own crits (See Figure 1).

[Figure 1 - Traditional design review set up]

The setting of these reviews also served to allow cohorts of students to display their work together, although in some schools presentation modalities made this impossible, with students required to present work from the entire semester as part of one presentation - displayed across all the walls of the studio. This approach depriving the design review of a key element; the ability for students to compare outputs and approaches (See Figures 2). Jury members were required to move positions three or four times during a single presentation, to ensure they able to view the work, a pattern that dwindled as the day progressed. 
[Figure 2 - Students' presentation covering three sides of the room]

This approach contributed further to trepidation's among students, who described that particular setting as: difficult, strained, or tense, sentiments expressed by students at different levels of the programme, and exemplified by a fourth year student below:

“... during presentations, you, $\ldots$ you find that, $\ldots$ there's an air of, $\ldots$ the atmosphere is very thick, it's, ... people are very tense, especially the person presenting, ... the mood is, is, is a very tense one, it is not relaxed, as such it limits the creativity." (FG3_1 - Year 4)

Such conditions impact on perceptions and enthusiasm for design review sessions, with some students suggesting they avoided interim design review sessions to evade the stress that accompanied these sessions. Interim reviews were also viewed as unimportant as they often did not contribute to what students valued most - marks. The lack of participation in interim design review sessions, left students hesitant to share ideas with their peers and instructors, further affecting their confidence and ability to present during final design review sessions. It was thus apparent that the temporal and physical setting of the design review contributed to negative perceptions by students, eroding its role as a learning opportunity integral to architectural education.

Notwithstanding the ubiquity of the traditional design review setup, there was evidence of change, with an attempt to reformulate the design review as observed in one school. Here, a setting, delineated the 'Back Seat Instructor', was implemented, and as the name implied, students took prime position at the front, with instructors relegated, physically and metaphorically to the rear. This approach had built on the theory, 'leading from behind', brought into contemporary discourse through Nelson Mandela's autobiography, A Long Walk to Freedom, in which he suggested a great leader is akin to a shepherd, who "... stays behind the flock, letting the most nimble go out ahead, whereupon the others follow, not realizing that all along they are being directed from behind" (Mandela, 1995). These back seat instructor sessions had two key objectives: i. to remove the association of power with setting of the design review; and, ii. to showcase the value of peer review, individual opinions and voices in architectural education (See Figure 3). 
[Figure 3 - Back Seat instructor session (Instructor at the extreme right)]

In these sessions students took the lead in reviewing work, encouraged to go beyond superficial comments, such as 'I like ...'or 'I don't like ...', and to give their peers critical feedback to aid the design process. Instructors only provided comments on general issues, guiding discussions toward reflective engagement, or where technical issues required clarification, while resisting the urge to override student comments, to help build students' confidence in expressing ideas. In providing peer feedback, students were required to ground comments and suggestions, providing examples from precedents to help in the design development process, while keeping in mind the objectives of the design studio and the particular design review session. Although used across all year levels of the school, this approach was particularly effective in the upper years of the architecture programme (third year and above), possibly a reflection of prolonged engagement with this activity, as reflected in one students' response:

"Your peers will ask you questions that you wouldn't have asked yourself, and it helps you realise your mistakes, and by the time the tutor actually comes to look at your work; you've already answered most of the things that a client would have asked." (FG2_3 - Year 1)

\section{Teacher-Student Relationship}

According to Oh et al. (2013), three types of teacher-student relationships can be seen in architecture education: i. the master-apprentice; ii. the user-designer; and, iii. the peer critique. These relationships reveal the diversity of experiences within architectural education, and the design review specifically. Crucially, these relationships showcase the cultural context and embedded pedagogical approach of the various schools. Two distinct approaches were evident across the region: the master-apprentice approach, tied to a largely patriarchy and seniority based culture and firmly entrenched in the legacy schools; while in the newer schools, a cordial user-designer or peer critique style was apparent. With regard to the former, one student stated: "... it's still the same old traditional kind of institution like arrangement, where there are gods and servants, subjects, and slaves, you know, masters and slaves (FG3_2 - Year 5)." The tensions suggested by such statements, also influenced how students perceived instructors, who were seen as being out of touch: 
"I think that instructors should be able to appreciate any new form of architecture that the student comes up with not just the old set standard way of designing you know ..." (FG5_8 - Year 6)

"Possibly their perspective doesn't capture what you really wanted to say, and uh, we have to appreciate like as in. As much as our lecturers might be having that experience, maybe your perspective is from the future, and their perspective is from the past." (FG8_6 - Year 3)

Generational tensions were carried into opinions on fashion and grooming, with some instructors taking particular interest in the students' choice of clothing, posture during presentations, and their diction. In design review sessions, instructors were observed berating students, in one case, a student with his shirt hanging out was severely cautioned (although his shirt had only come undone when he was stretching to a part of his presentation panel). Such engagements extended beyond jibes at fashion choices, to how presentation panels were to be laid out - irrespective of the project. This served to promote an 'us-versus-them' position, with students believing these were attacks directed at their generation, and on generational expression, as presented by some students: “ $\ldots$ but if they are being judged by maybe dreadlocks or, I don't know, or something like that, which may not necessarily be the dress code, but you know that kind of thing" (FG3_5 - Year 5); "They already know the way you dress, the way you talk, the way you do your things, so maybe it helps develop criteria of awarding the marks" (FG5_9 - Year 6). Unburdened by the traditions of the older schools, newer schools were observed to have less authoritative conditions, evident in the discussions: "So I think it helps to be friendly with the lecturers. And of course you are friendly even when they criticise, cause they do that all the time, You do not take it in a defensive way, something like that ..." (FG4_3 - Graduate). Students in the upper years of programmes valued this approach, given engagements between faculty and students was cordial and friendly:

"I've noticed, as you progressed over the years, the tutors became more, I can't say more humane, but they invited us more to discus with them and we felt freer to discuss with them ..." (FG5_11 - Year 3)

Overall, relations between faculty and students presented the design review as particularly judgmental, often shutting out the possibility of thoughtful dialogue. The design review thus became just another hoop to jump through, with students seeking 
to defend their work at all costs, and in so doing unable to capitalise on the learning opportunities it presented.

\section{Communication Modalities}

Within the design review, communication modalities between instructors and students may take the form of: conversations, written comment, drawings, and gestures (Oh et al., 2013). While courteous communication can have an uplifting effect on students, contributing to design development, the opposite can leave students feeling anxious, lost, and bewildered. Different modes of communication were observed at different points and to stress different ideas within the design review. By far, verbal communication was the most used, with instructors giving students comments after each presentation; a lengthy process, with each jury members keen to give their views and opinions to students. This often led to students receiving contradictory advice, and with little time for proper engagement between inductors and students, contributing to the perception of the design review as being about the instructors. In addition, verbal feedback was not always clear, and thus easily misinterpreted by students who were often too nervous or overwhelmed with information to take in the comments. Aware of the challenges associated with giving oral feedback, one school of architecture supplemented this with a written summary provided to each student after major design review sessions. These written summaries then served as the basis for discussions in subsequent crit, and design review sessions. Producing these summaries was described as being a tedious process, and thus were largely undertaken for higher level studio courses, although it was indicated that software such as the Additio $A p p \AA$ did make this process easier, and useable for lower level studio with larger student numbers Beyond oral communication, and the limited efforts at written feedback, there was scant evidence of feedback communicated through drawing in design review sessions, more so as these were often summative assessment presentations. The absence of drawing raises questions of the design review as a discursive learning opportunity, given drawing as a key component in architectural communication between students and instructors was conspicuously absent. Overall, students viewed the modes of communication used in the design review as inadequate, affecting their ability to learn: 
“... we have very poor feedback, and why is that, teacher student

relationship has been so very low." (FG6_5 - Year 3)

"... the rigidity of the tutors in the end may come, at times shuts our innovative, how can I call it, qualities in a way, at times you get to fear them so much, that you fear that they can mess up your marks, so you end up having to take their suggestions." (FG2_1 - Year 2)

Such struggles may relate to more than just communication modalities, but to negative expectations students held of the design review, and the nebulous nature of the architectural design process, This was further complicated by the design review being undertaken to evaluate the product only (design outcomes), neglecting the design process as a fundamental part of the development of architectural proposal. This served to remove any opportunity for further development of ideas, thus negating a key purpose of the design review - the opportunity for discussion and reflection.

\section{Delivery Types}

How feedback is delivered to students can be either facilitative - aiding the development of reflective learning, or directive - reiterating the dominant paradigm of the instructors (Oh et al., 2013). The nature of feedback delivered would thus influence how students engaged with the design process, a directive approach not particularly useful in developing a critical mind. The design review was valued in providing useful feedback, through and approach that was appreciated for being different from that found in pre-university education:

"So normally in school, in high school, you're listening, you listen, you do your exam and you finish. But, then when you join architecture, it's not a matter of being taught. You have to; you are just being guided. You have to go out, out of your way and discover. And then, even when they are giving, when they are correcting you, you learn to, to make it not personal, cause at the end of it all, at the end of it all, they are just trying to help you, so you make it not personal, so that you can, so that you can progress ..." (FG5_6 Year 3)

Despite this acknowledgement, the directive approach was found to dominate across the schools. This approach was perceived by students as restricting their design 
endeavours, leading students to view instructors as being inadequately prepared for teaching engagements, as well as being authoritative, and unyielding in their views of architectural design. Feedback through the directive approach is also not conducive to building life-long learning skills, important in contemporary architectural education.

"... the rigidity of the tutors in the end may come, at times shuts our innovative, how can I call it, qualities in a way, at times you get to fear them so much, that you fear that they can mess up your marks, so you end up having to take their suggestions." (FG2_1 - Year 2)

There are historical reasons for this educational approach; a response to a scarcity of teaching material during the 1980s and 1990s, however, its persistence, despite increased access to resources and information, may indicate a more complex set of guiding factors, including recruitment practices, and limited professional development for educators. With only a few examples of facilitative engagement evident, the predominance of ritualistic and prescriptive views may contribute to the tensions between instructors and students, as noted by one recent graduate:

"We had a lecturer, ok an ex soldier, or something (Dr. Ing.) sincerely this is a guy who, ... it was like you were competing with him, and ... of course, you don't know, he knows, he is the instructor" (FG4_3 - Graduate)

Delivery of feedback to students, was on the whole geared more to training and replication, rather than educating designedly thinkers, raising questions not only of the nature of teaching, but also perceptions of architecture and architectural education. As the statements from students suggest, this does have a profound impact on their learning, and engagement with architectural design activities.

\section{Delivery Methods}

Associated with delivery types, are the methods of delivery, which include: body language (facial expressions and hand gestures), intonation and loudness of instructors, and the style of drawing when giving feedback (Oh et al., 2013). Delivery methods convey diverse messages to students, and relate to their desire for affirmation and approval from instructors; students depend on this as an acknowledgement of their efforts and accomplishments. For students, delivery methods were cited as an indicator of how instructors viewed their work. Students recalled situations in which their presentations were interrupted, or where jury 
members asked (rhetorical) questions, conveyed with raised voices, and frustrated intonations, as expressed by one student: “They are like, 'you don't listen to us', or 'we are your tutors here, we have the final say' you know" (FG2_4 - Year 3). On a few occasions, jury members often gave sarcastic or facetious comments to students, in one case stating, "nice trees" with reference to a student's poster which had trees meticulously coloured green, but the rest of the drawing left bare, leaving the jury pondering whether this was an architectural presentation. In a different school, on seeing a students work, one juror suggested that the student should give up architecture, as his presentation was not what the juror expected: “... so I was told that, you can't be an architect, just that, there was no explanation why" (FG3_6 Year 4). These were not isolated cases, with students suggesting such comments were commonplace:

“. $\ldots$ there were times when some instructor would openly declared, 'I am going to purge these kind of students'. There is one who declared, and I appreciated that instructor for that, because, at first I thought, 'what is wrong with this man' and then he declares 'I am going to purge, these kinds of people, and these kind of people I will lift." (FG4_2 - Graduate)

To counter this, students approached their presentations in an offensive approach, with the design review where they convey "... design intentions across to the Jurors at all costs" (Alagbe et al., 2017: 4544), possibly contributing to their own disenfranchisement, with members of the jury proceeding to dig in their heals. As noted in the section on 'Communication Modalities', drawing on, or marking up student work was only evident in a few cases. When used in the delivery of feedback, instructors made use of different coloured felt pens to highlight elements of designs that needed further attention, and only in a few cases made suggestions for improvements. Despite these efforts, students having had little or no sleep, stood by bewildered, and did not appreciate this engagement as an important part of design studio pedagogy, perceiving it as discrediting their work. This perception of feedback further heightening the divide between instructors and students, entrenching the idea that there wasn't adequate support for the growth of architectural designs ideas, or for the development of designedly ways of thinking and acting.

\section{Contextualising the Design Review}


The findings of the study suggest that the design review in East Africa is not the discursive environment expected, but rather a source of anxiety and trepidation for students. This is fuelled by the jurors' authoritarian approach that supports an assertion by Sara and Parnell, that "the present culture [of architectural education] seems to be more about fear, than learning" (Sara and Parnell, 2013: 123). Of particular concern were the tactics employed, compel students - regardless of their year level - to follow the dominant narrative in order to succeed. This was somewhat linked to institutionalised structures, and in some cases, embedded seniority, patriarchal and hegemonic traditions that are still found within educational systems across East Africa; far from the collegiate discursive environment envisioned for contemporary architectural education. This ties to the notion of epistemic injustice as presented by Fricker (2003), in which knowledge of one group is diminished in value merely because of their social standing. The denigration of students' ideas in the design review bears similarities to epistemic injustice, and has been somewhat normalised in architectural education. The reality is that many instructors in architectural education have not received formal education or training in educational pedagogy, effectively 'learning by doing', in parallel with their students (Goldschmidt et al., 2010), in an 'apprenticeship of observation' approach (Shulman, 2005), derived from their own education, or from senior instructors. The approach to teaching in architectural education thus emerges as a common denominator in the expressed views of students, and in observations made in schools across the region.

Although the dominant narrative within the design review suggested coercion as a core element in the engagement between instructors and students, there was evidence of a developing counter narrative against this. Through the alternative formats of the design review, such as the Back Seat Instructor, attempts are being made to recast the power dynamics of the design review, acknowledging its formative role in architectural education. Employing unconventional approaches to the design review, are significantly important in the move away from traditional power structures and hegemonic traditions, which have eroded the value of this educational approach. In the context of East Africa, these may represent the genesis of educational approaches that confront entrenched prejudices and challenging established power structures, pedagogical approaches, and assessment procedures, which have considerably eroded confidence in the design review as discursive educational tool. 
At a broader level, such changes may serve as an important turning point in the conduct of the design review, and how students and instructors perceive its purpose and value.

\section{Conclusions}

For anyone involved in a design review, the experiences showcased in this paper may be familiar. Presented from a students' point of view, the findings raise questions of the design review as part of the signature pedagogy of architectural education. The ritualised nature of architectural education may in part be to blame, with techniques largely derived from previous experiences of instructors, but presented as the norm. We are thus left to consider the fact that "... the way we teach will shape how professionals behave - and in a society so dependent on the quality of its professionals, that is no small matter" (Shulman, 2005: 59). This raises concerns about the quality of teaching in architectural education, and how this could impact on the wider profession. For students, who did feel somewhat disenfranchised, alternative approaches such as the 'back seat instructor approach', are an important element in reframing the design review as part of the signature pedagogy of architectural education, and in so doing, helping turn this engagement into a genuine transactional and discursive interaction.

Given the contribution of practices in the design review to socialisation in architectural education, the impetus for change is clearly apparent. This is not only to protect the integrity of the design review, but also to ensure the effectiveness of the design studio in architectural education. The findings of the current study present a number of lessons for architectural educations, and from which the following recommendations are derived:

- Provide instructors with guidance in good teaching and assessment practices, with emphasis on design studio pedagogy, and stressing the value of the design review as an important learning opportunity;

- Ensure students are fully aware of project learning goals and the role of the design review as an opportunity for dialogue on design, thus building an appreciation of the reflexive nature of architectural education; 
- Alternative presentation approaches, such as the back seat instructor, are invaluable in dispelling the myths associated with the design review, and promoting a less confrontational atmosphere between instructors and students;

- Encouraging full participation in all activities of the design studio, by both instructors and students to ensure the benefits of this learning opportunity are achieved.

These recommendations could help improve interactions within the design review in architectural education, but by no means is this list exhaustive. Such improvements would also contribute to dispelling some of the myths that surround the design review, thus uncloaking the black box of architectural education, for instructors and students alike. The end goal regardless should be to improve teaching quality, and learning outcomes through a systematic approach in which activities are focused on excellence in architectural education, more so in the design review.

\section{Bibliography}

Aderonmu PA, Awoyera PO, Sholanke AB, et al. (2017) Professional methods of assessments in architectural design projects: A focus on the relevant parametric measures in selected Nigerian universities. Cogent Social Sciences 3(1).

Alagbe O, Aderonmu P, Alagbe T, et al. (2017) Students' perceptions of design studio jury in schools of architecture in Nigeria. In: Gómez Chova L, López Martínez A and Candel Torres I (eds) 11th International Technology, Education and Development (INTED) Conference. Valencia, Spain: IATED Academy, 4542-4546.

Alagbe O, Aderonmu P, Opoko AP, et al. (2015) Comparison of design studio and jury systems in architectural schools in southwest Nigeria. Global Journal on Humanities \& Social Sciences (1): 430-435.

Allan G. (2003) A critique of using grounded theory as a research method. Electronic Journal of Business Research Methods 2(1): 2-8. 
Anthony KH. (1991) Design Juries on Trial: The Renaissance of the Design Studio, New York: Van Nostrand Reinhold.

Argyris C and Schön DA. (1974) Theory in Practice: Increasing Professional Effectiveness, San Francisco: Jossey-Bass Publishers.

Boyer EL and Mitgang LD. (1996) Building Community: A New Future for Architectural Education and Practice, Princeton, N.J.: The Carnegie Foundation for the Advancement of Teaching.

Bragg AK (1976) Socialization process in higher education, ERIC/Higher Education Research Report No. 7, Publications Department, American Association for Higher Education, Washington, DC, available at: http://eric.ed.gov/?id=ED132909 (accessed 31 January 2019).

Bulmer M and Warwick DP. (1993) Social Research in Developing Countries: Surveys and Censuses in the Third World. London: Routledge.

Camfield L, Duvendack M and Palmer-Jones R. (2014) Things you wanted to know about bias in evaluations but never dared to think. IDS Bulletin 45(6): 49-64.

Coetzer N. (2010) Towards a dialogical design studio: Mediating absurdities in undergraduate architectural education in South Africa. South African Journal of Art History 25(1): 101-117.

Cook-Sather A. (2002) Authorizing students' perspectives: Toward trust, dialogue, and change in education. Educational Researcher 31(4): 3-14.

Cuff D. (1991) Architecture: The Story of Practice, Cambridge, Mass.: The MIT Press.

Dannels DP. (2005) Performing tribal rituals: A genre analysis of "crits" in design studios. Communication Education 54(2): 136-160.

Doidge C, Sara R and Parnell R. (2000) The Crit: An Architecture Student's Handbook. Amsterdam: Architectural Press.

Esser-Hall G, Rankin J and Ndita DJ. (2004) The narrative approach in art education: A case study. Journal of Art and Design Education 23(2): 136-147. 
Fricker M. (2003) Epistemic injustice and a role for virtue in the politics of knowing. Metaphilosophy 34(1/2): 154-173.

Fung S. (1996) Notes on the architectural education of nomads. Architectural Research Quarterly 2(2): 10-17.

Goldschmidt G, Hochman H and Dafni I. (2010) The design studio "crit": Teacherstudent communication. Artificial Intelligence for Engineering Design, Analysis and Manufacturing 24(3): 285-302.

Gore JM. (1995) Foucault's poststructuralism and observational education research: A study of power relations. In: Smith $\mathrm{R}$ and Wexler $\mathrm{P}$ (eds) After Postmodernism: Education, Politics And Identity. London: The Falmer Press, 98-111.

Graneheim UH and Lundman B. (2004) Qualitative content analysis in nursing research: Concepts, procedures and measures to achieve trustworthiness. Nurse education today 24(2): 105-112.

Gul CGG and Afacan Y. (2018) Analysing the effects of critique techniques on the success of interior architecture students The International Journal of Art \& Design Education 37(3): 469-479.

Hammersley M and Atkinson P. (1983) Ethnography: Principles and Practice, London: Tavistock Publications.

Hattie J and Timperley H. (2007) The power of feedback. Review of Educational Research 77(1): 81-112.

Jo S and Lee K. (2007) Architecture as narrative: On Bernard Franken's ruminations on characterization, integration, and imagination. Journal of Asian Architecture and Building Engineering 6(2): 213-220.

Mandela N. (1995) Long walk to freedom: The autobiography of Nelson Mandela, New York, N.Y.: Back Bay Books.

McClean D and Hourigan N. (2013) Critical dialogue in architecture studio: Peer interaction and feedback. Journal for Education in the Built Environment 8(1): 35-57. 
Mills $G$ and Lipman A. (1994) Society and architectural education in South Africa Are universities appropriate venues for schools of architecture? Environment and Planning B: Planning and Design 21: 213-221.

Oh Y, Ishizaki S, Gross MD, et al. (2013) A theoretical framework of design critiquing in architecture studios. Design Studies 34(3): 302-325.

Olweny M. (2017) Socialisation in architectural education: A view from East Africa. Education + Training 59(2): 188-200.

Olweny MRO. (2015) Investigating the Processes of Socialisation in Architectural Education: Through Experiences in East Africa. Welsh School of Architecture. Cardiff: Cardiff University.

Onwuegbuzie AJ, Dickinson WB, Leech NL, et al. (2009) A qualitative framework for collecting and analyzing data in focus group research. International Journal of Qualitative Methods 8(3): 1-21.

Osborne L and Crowther P. (2011) Butterpaper, sweat \& tears: The affective dimension of engaging students during the architectural critique. In: Elkadi $\mathrm{H}$, $\mathrm{Xu} \mathrm{L}$ and Coulson $\mathrm{J}$ (eds) International Conference of the Association of Architecture Schools of Australasia. Geelong, Vic., Australia: Deakin University, School of Architecture \& Building.

Owuor JA. (2007) Integrating African indigenous knowledge in Kenya's formal education system: The potential for sustainable development. Journal of Contemporary Issues in Education 2(2): 21-37.

Sara R and Parnell R. (2013) Fear and learning in the architectural crit. Field Journal 5(1): 101-125.

Schön DA. (1985) The Design Studio: An Exploration of its Traditions and Potentials, London: RIBA Publications Ltd.

Shannon S. (1995) The Studio Critique In Architectural Education. Department of Architecture. Adelaide: University of Adelaide, 392.

Shulman LS. (2005) Signature pedagogies in the professions. Daedalus 134(3): 5259. 
Smith C. (2011) Understanding students' views of the crit assessment. Journal for Education in the Built Environment 6(1): 44-67.

Stevens G. (1995) Struggle in the studio: A Bourdivin look at architectural pedagogy. Journal of Architectural Education 49(2): 105-122.

Vowles H. (2000) The 'crit' as a ritualised legitimation procedure in architectural education. In: Nicol D and Pilling S (eds) Changing Architectural Education: Towards A New Professionalism. London: E \& FN Spon, 259-264.

Webster H. (2005) The architectural review: A study of ritual, acculturation and reproduction in architectural education. Arts and Humanities in Higher Education 4(3): 265-282.

Webster H. (2006) Power, freedom and resistance: Excavating the design jury. International Journal of Art and Design Education 25(3): 286-296.

Webster H. (2007) The analytics of power: Re-presenting the design jury. Journal of Architectural Education 60(3): 21-27.

Wilkin M. (2000) Reviewing the review: An account of a research investigation of the 'crit'. In: Nicol D and Pilling S (eds) Changing Architectural Education: Towards A New Professionalism. London: E \& FN Spon, 100-107. 